Москальова Людмила Юріївна доктор педагогічних наук, професор, проректор, Мелітопольський державний педагогічний університет імені Богдана Хмельницького, вул. Гетьманська, 20 м. Мелітополь, 72300, тел.: (0619) 44-04-64, e-mail: moskalevalu1@gmail.com, https://orcid.org/0000-00029251-6746

Чорна Вікторія Володимирівна кандидат педагогічних наук, доцент, Мелітопольський державний педагогічний університет імені Богдана Хмельницького, вул. Гетьманська, 20 м. Мелітополь, 72300, тел.: (0619) 44-04-64, e-mail: chernajaviki@gmail.com, https://orcid.org/0000-0002-0007-470X

\title{
КІБЕРБУЛІНГ СЕРЕД СТУДЕНТСТВА: СУЧАСНА ПСИХОЛОГІЧНА ПРОБЛЕМА
}

Анотація. Зростання випадків кібер-булінгу та випадків, пов'язаних із кібер-залякуванням спонукало дослідників, педагогів, державних службовців та батьків до вивчення їх причин. Існуючі дослідження щодо кібер-булінгу в основному не мали належної теоретичної основи. Крім того, попередні дослідження зосереджені на дітей та підлітках; емпіричного дослідження поведінки кібер-булінгу серед студентів університетів майже має. Спираючись на соціальну когнітивну теорію та зосереджуючись на віковій групі студентство, у статі автори підтверджують великий вплив особистих факторів та факторів навколишнього середовища на особистість майбутнього фахівця та його участі у організації кібер-залякуванні та кібербулінгу. Результати дослідження також показують, що соціальні норми, а також фактори, такі як популярність в Інтернеті, мотивація та досвід кібервіктимізації, $є$ сильними предикторами поведінки студентів університетів у кібер-залякуванні. Це дослідження не лише збагачує наше розуміння детермінант поведінки кібербулінгу з боку студентів університетів, але й надає цінну інформацію для педагогів, батьків та усіх, хто цікавиться цією проблематикою.

Кібербулінг $є$ актуальною проблемою в контексті вищої освіти, оскільки інформаційно-комунікаційні технології (IКТ) все більше стають частиною повсякденного життя в університеті. Загальні результати роботи дозволяють визначити основні фактори, що спричинюють кібербулінг в університетському середовищі: агресія у відносинах, когнітивно-афективний дефіцит влади та контролю. Таким чином, дослідження надає теоретичну інформацію про кіберзалякування в університетському осередку, що має потенціал для розробки більш відповідної політики та програм / рішень втручання для вирішення цієї 
поведінки.

Результати цього дослідження є особливо актуальними, оскільки вказують на те, що програми інтервенцій мають враховувати вплив емоційного інтелекту, а також актуальність адаптації студентів до університетського життя.

Ключові слова: кібербулінг, здобувачі вищої освіти, психологічні причини кібербулінгу

Moscalyova Luydmyla Yuriivna Doctor of Pedagogical Science, Professor, vice-rector, Bogdan Khmelnitsky Melitopol State Pedagogical University, Hetmanskya St., 20, Melitopol, 72300, тел.: (0619) 44-04-64, e-mail: moskalevalu1@gmail.com, https://orcid.org/0000-0002-9251-6746

Chorna Viktoriia Volodymyryvna, Candidate of Pedagogical Science, docent, Bogdan Khmelnitsky Melitopol State Pedagogical Ubiversity, Hetmanskya St., 20, Melitopol, 72300, тел.: (0619) 44-04-64, e-mail: chernajaviki@gmail.com, https://orcid.org/0000-0002-9251-6746

\section{CYBERBYLING BETWEEN STUDENTS: MODERN PSYHOLOGY PROBLEM}

Abstract. The rise of cyberbullying has prompted researchers, educators, government officials and parents to study their causes. Existing research on cyberbullying has largely lacked a proper theoretical basis. In addition, previous research has focused on children and adolescents. There is almost no empirical study of cyberbullying behavior among university students. Based on social cognitive theory and focusing on the age group - students, the authors confirm the great influence of personal and environmental factors on the future specialist personality and its participation in the organization of cyber-intimidation and cyberbullying. The results of the study also show that social norms, as well as factors such as online popularity, motivation and experience of cyber-victimization, are strong predictors of the behavior of university students in cyber-intimidation. This research work is not only enriches our understanding of the cyberbullying behavior determinants by university students, but also provides valuable information for educators and anyone interested in the issue.

Cyberbullying is a pressing issue in the context of higher education, as information and communication technologies (ICT) are increasingly becoming part of everyday life at the university. The general results of the work allow to determine the main factors that cause cyberbullying in the university environment: aggression in relationships, cognitive-affective deficit of power and control. Thus, the research work provides theoretical information on cyberbullying in the university, which has the potential to develop more appropriate policies and intervention programs / solutions to address this behavior. 
The results of this research work are particularly relevant because they indicate that intervention programs should take into account the impact of emotional intelligence, as well as the relevance of students' adaptation to university life.

Keywords: cyberbullying, higher education seekers, psychological causes of cyberbullying

Постановка проблеми. Наразі все більше наукових досліджень розглядають питання кібербулінгу в університетському середовищі, виявляючи, що у сучасній вищій освіті присутнє це явища. У більшості джерел, кібербулінг визначається як навмисна та неодноразова шкода, заподіяна шляхом використанням комп'ютерів, мобільних телефонів та інших електронних пристроїв. Широке використання інформаційно-комунікаційних технологій, особливо молодими людьми, змінило те, яким чином суспільство отримує доступ до інформації, як ми спілкуємося та взаємодіємо з іншими.

Безперечно, в цьому є свої переваги, але також існують проблеми, що пов'язані 3 неналежним використанням цих нових технологій. Таким чином, деякі явища, які зазвичай асоціюються зі університетським середовищем, як-от булінг, знайшли свої еквіваленти в нових віртуальних сценаріях чи реаліях. Студенти та підлітки, які володіють високою цифровою кваліфікацією, використовують їх, щоб агресивно поводитися по відношенню до своїх однолітків (погрози, переслідування, хабарі, образи, приниження, публікація конфіденційної інформації, крадіжка особистих даних, маніпулювання фотографіями, записування та поширення фізичної агресії тощо).

Аналіз останніх досліджень і публікацій. Існує багато досліджень щодо кібербулінгу в підлітковому віці, однак останнім часом високі показники поширеності також були виявлені і в університетському середовищі. Таким чином, дослідники припускають, що кількість студентів, які стали жертвами кібербулінгу під час навчання у вищій школі, може коливатися від 5 до 40\%. Так, А. Фінн використовуючи широку вибірку студентів, виявив, що від 10 до 15\% здобувачів вищої освіти підтвердили, що отримували електронні листи або повідомлення $з$ погрозами, образами чи переслідуваннями [1]. А. Ліндсей i К. Крисік виявили вищі показники поширеності серед вибірки 3420 студентів університету, наголошуючи, що 43,3\% здобувачів вказали, що постраждали від кібербулінгу [2]. Т. Фейчек використовуючи вибірку з 1925 студентів, виявив, що 24,1\% здобувачів стали жертвою кібербулінгу протягом останнього року [3]. П. Залакетт і Р. Чаттерс у своєму дослідженні виявили, що 19\% із вибірки 3 613 студентів університету повідомили, що були жертвами кібербулінгу, тоді як 5\% повідомили, що були агресорами кіберзалякування [4]. Різні показники поширеності є досить високими, можливо, через різну концепцію кібербулінгу, різні використовуванні методики або визначення частоти, необхідної для того, щоб вважатися кібербулінгом. Незважаючи на цю мінливість, емпіричні дані підтверджують наявність цієї проблеми в університетських умовах.

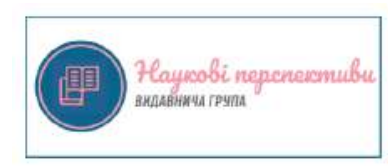


Саме тому метою статті є 3'ясування причин та можливих шляхів протидії цифровому булінгу в універсітетському середовищі

Виклад основного матеріалу. 3 огляду на статистичні дані, кіберзалякування стало актуальною соціальною проблемою, враховуючи іiі високу поширеність та серйозні наслідки. Це, в свою чергу, призвело до реалізації дослідження, спрямованого на визначення проблеми та шляхів запобігання цифровому насильству.

Кібербулінг є результатом сформованості особистісних характеристик студента та впливу середовища, в якому ці характеристики розкриваються. Університетський простір і зміна життєвої фази майбутніх фахівців протягом цього періоду мають деякі специфічні характеристики, які відрізняються від інших життєвих фаз (дитинство чи юність) або освітніх циклів (початкова чи середня освіта). Це безперечно може вплинути на появу кібербулінгу та цифрового насильства, і тому їх слід уважно розглянути. Більшість студентів університетів переживають нову фазу життя, яка називається дорослим життям (де мають місце нові поведінкові, когнітивні та соціальні чи афективні реакції у відповідь на нові вимоги оточуючого середовища). Університетська фаза збігається 3 цією новою роллю дорослого, оскільки вона вимагає розгляду нових сценаріїв дії, які відзначаються відокремленням від батьків та шкільних друзів, створенням нових соціальних кіл і потребою у підвищенні автономії та відповідальності. Отже, поряд із підвищеними академічними вимогами, які можуть визначати їхнє майбутнє у професійній сфері, студенти університетів також стикаються 3 додатковими соціальними та емоційними проблемами. Багато досліджень виявили, що велика кількість студентів стикаються 3 академічними чи емоційними проблемами. Депресія, тривога та стрес були виявлені у високого відсотка здобувачів віщої освіти. Психосоціальні фактори та особливості університетського життя (конкурентне академічне середовище, перенавантаження, відсутність міцних стосунків 3 однолітками, безробіття тощо), що притаманні саме студентству, значно відрізняються від інших рівнів освіти та пов'язані зі зниженням психічного здоров'я. 3 іншого боку, щодо зв'язку між кібербулінгом та емоційними проблемами (тривожністю, депресією та стресом), значна кількість емпіричних досліджень виявила високі показники цих проблем у жертв кібербулінгу. Таким чином, можемо припустити, що ці здобувачі демонструють високий рівень тривоги, депресії, стресу, низької самооцінки, безсилля, самотності, гніву, розладів сну, проблем 3 концентрацією, низької успішності та прогулів, і навіть суїцидальні думки, внаслідок того, що вони стали жертвою знущань, принижень, домагань тощо, у той час як кіберхулігани демонструють не нормо типову поведінки, низьку емпатію, агресивну поведінку та прогули, а також тривогу, депресію, та психосоматичні симптоми.

Таким чином, в умовах університету емоційні проблеми можуть бути виявлені у великого відсотка здобувачів та не обов'язково пов'язані 3 
кібербулінгом, хоча стан жертви або агресора кіберзалякування може призвести до розвитку високого рівня тривоги, депресії та стресу у студентів, встановлення складних зв'язків між цими конструктами. Підкреслимо, що деякі студенти відчувають високий рівень тривоги, депресії та стресу під час цього конкретного періоду змін, багато 3 цих емоційних проблем можуть бути результатом того, що здобувачі стали жертвою або агресором кібербулінгу. Це останнє припущення знайшло широке підтвердження в науковій літературі. Отже, тривога, депресія, стрес та інші емоційні проблеми можуть бути наслідком віктимізації, але також можливо, що депресивні студенти, маючи високий рівень тривоги чи стресу, можуть стати жертвами залякування через їх неадекватну соціальну поведінку, відсутність самооцінки або нездатність захистити себе через депресію, тривогу або стрес, які вони переживають. Аналогічно, депресивний здобувач з високим рівнем тривоги або стресу може мати низький рівень сприйняття однолітками, що, в свою чергу, призводить до змін у поведінці і, таким чином, перетворює їх на агресорів. Зв'язок між шкільним знущанням та соціальними проблемами є взаємним. Додамо, що що страждання від кіберзалякування або власне кіберзалякування може призвести до емоційних проблем, існують емпіричні докази щодо зв'язку між стражданням від емоційних проблем та здатністю студента бути жертвою або агресором кібербулінгу. Більшість із цих досліджень зосереджені на підлітковій популяції, проте деякі дослідження розглядали і студентський осередок.

3 іншого боку, деякі дослідження відзначають контекстуальні змінні, наприклад ті, які беруть участь у адаптації студента до академічного середовища. Таким чином, хоча адаптація до університетського сердовища була концептуалізована 3 різних точок зору, одна 3 найбільш загальноприйнятих точок зору була встановлена Б. Бейкером і В. Сіриком[5]. Було виявлено, що у студентів, як правило, різні типи адаптації до навчального процесу в університеті: академічну (виконання освітніх запитів університету), соціальну (протистояння міжособистісним вимогам університету), особистісно-емоційну (фізичне та психологічне комфортне самопочуття), а також інституційний зв'язок (приємне ставлення до університету загалом і якісний зв'язок з обраним закладом). Багато досліджень припускають, що низький рівень адаптації до університету може мати значний негативний вплив на здобувача. Що стосується зв’язку між адаптацією до університету та кібербулінгом, то очевидно, що страждання від булінгу або кібербулінгу на минулих етапах навчання (початкова чи середня освіта) може передбачити гіршу адаптацію до університету, а також психосоціальні проблеми. Здобувачі, які згадували про те, що були жертвами кібербулінгу під час здобування початкової освіти, демонстрували академічні, міжособистісні проблеми та проблеми 3 самооцінкою під час навчання в університеті, тоді як студенти, які постраждали від кібербулінгу під час середньої освіти, та ті, хто стали жертвами протягом обох попередніх періодів навчання (початкової та середньої освіти) в 
університеті мали проблеми міжособистісного характеру та низької самооцінки. Постраждалі від кібербулінгу під час середньої освіти зазвичай мають низький рівень соціальної та особистісно-емоційної адаптації до навчання в університеті. Але наразі існує лише декілька досліджень, що з’ясовують, чи $\epsilon$ ця адаптація залежною величиною того, щоб стати жертвою чи агресором кібербулінгу. Наскільки нам відомо, дослідження, проведене Соуза Б. та ін. єдине актуальне дослідження 3 цього приводу. Ці автори, використовуючи вибірку з 979 студентів університетів, виявили, що пристосування новачків до студентського життя та відчуття внутрішнього спокою не $є$ гарантією для студента і вони не виключають, що можуть стати жертвою або агресором кібербулінгу [6].

Автори цього дослідження вважають, що ситуацію можна виправити шляхом визначення змінних, що передбачають ймовірність стати жертвою чи агресором кібербулінгу. Якщо рівні тривоги, депресії та стресу чи адаптації до навчання в університеті 3 його чіткими вимірами (академічним, соціальним, особистісно-емоційним та інституційним) фактично передбачають кібербулінг, це означає, що методи профілактики чи втручання мають бути спрямовані саме на ці змінні. Отже, мета цього дослідження - проаналізувати прогностичну силу тривоги, депресії, стресу та адаптації до університету для того, щоб стати жертвою чи агресором кібербулінгу у вищих навчальних закладах. Беручи до уваги обмежену кількість попередніх досліджень у цій галузі, ми очікуємо: 1. високий рівень тривоги, депресії та стресу, що є показниками того, чи можна стати жертвою чи агресором кібербулінгу; 2. окремі фактори адаптації до навчання університету (академічна, соціальна та особистісно-емоційна адаптації та інституційне пристосування) $є$ провісниками того, щоб стати жертвами чи агресорами кібербулінгу.

Емоційні проблеми здобувачів $є$ провісниками того, що людина стала жертвою або агресором кібербулінгу. Зокрема, високий рівень депресії та стресу передбачає більшу ймовірність стати жертвою кібербулінгу, тоді як ймовірність стати жертвою кіберзалякування зростає, коли у студентів високий рівень депресії. Констатуємо, що лише кілька досліджень торкалися питання, чи є ці високі показники результатом прогностичних змінних кібербулінгу в університеті. Також зрозуміло, що специфічні характеристики цього періоду можуть передбачати емоційні проблеми серед студенства. У нашому дослідженні виявлено, що ці проблеми збільшують ймовірність стати жертвою або агресором кібербулінгу. Таким чином, депресія передбачає ймовірність стати як агресором, так і жертвою. Вона впливає на соціальні навички та впевненість в собі, що призводить до труднощів у встановленні контактів 3 однолітками, що потенційно може призвести до певної поведінки у агресорів. Агресивна та домінуюча поведінка у кіберхуліганів походить від почуття нещастя, незадоволеності життям, депресії та високого рівня гніву чи люті. 3 іншого боку, депресивні особи можуть експериментувати із соціальною 
ізоляцією, відчуттям безглуздості міжособистісних проблем і негативним уявленням про себе, що робить здобувача більш вразливим. Ці труднощі, разом 3 іншими обставинами, можуть призвести до того, що студент буде більш вразливим до страждань від кібербулінгу через підвищений рівень депресії. Виявили, що зв'язок між депресією та шкільним цькуванням був двостороннім, таким чином, депресія може виступати як предиктор булінгу, а цькування бути провісником депресії. На наш погляд, дійсно існує двосторонній зв'язок між віктимизацією та проблемами інтеріоризації. Депресія, тривога, страх, невпевненість або низька самооцінка - все це схиляло студента до того, щоб стати жертвою. Аналогічно, стрес, що має місце в освітньому середовищі, через його великі вимоги, що ставить здобувачів у емоційне та соціальне невигідне становище i, таким чином, робить їх більш вразливими до кібербулінгу.

Що стосується соціальної адаптації, то можна стверджувати, що жертви кібербулінгу демонструють погану соціальну адаптацію (труднощі знайти друзів, погані стосунки 3 однолітками, відсутність соціальних навичок) порівняно 3 не-жертвами. Таким чином, констатуємо, що якісна особистісноемоційна та соціальна адаптація діє як захисний фактор, щоб не стати жертвою знущань, принижень чи домагань через цифрові медіа.

Особистісно-емоційна, академічна та інституційна адаптація $\epsilon$ провісниками того, що в університеті може мати місце кібер-залякування, причому ймовірність того, що здобувач стане кіберхуліганом зменшується в залежності від рівня цих пристосувань. Емоційні навички допомагають студентам відчувати більший рівень емпатії до своїх одногрупників, що може значно зменшити їхню участь у залякуванні; однак, одна з характеристик, яку зазвичай згадують кібер-хулігани - це низький рівень емпатії до жертв, оскільки вони, не демонструють хвилювання або провини у результаті своєї агресії, нездатні співчувати емоціям або почуттям жертви. Кібер-хулігани, як правило, демонструють низьку академічну успішність із низькою інтеграцією в академічне та навчальне середовище.

Отже, наявність позитивної академічної адаптації (мотивація до виконання академічних вимог, академічних зусиль i задоволеність академічним середовищем) діє як захисний фактор від агресивної поведінки по відношенню до однолітків. Що стосується інституційної адаптації та задоволеності студентів загальним досвідом навчання в університеті, якістю взаємин між студентом і закладом, то це також є захисним фактором від того, щоб стати кібер-хуліганом. Тому задоволеність студентів інституційною атмосферою університету $\epsilon$ важливим фактором, який слід враховувати, намагаючись запобігти або втрутитися у кібербулінг. Університети відрізняються своєю організаційною структурою, правилами спільної взаємодії та типом відносин, які встановлюються між студентами та рештою освітянської спільноти. Хоча деякі університети мають позитивне та інтегральне середовище, існують і такі, у яких студенти відчувають себе виключеними з навчально-виховного процесу 
і не відчувають, що вони належать до навчального закладу. У таких закладах ймовірність виникнення ситуацій булінгу серед студентів набагато більша. Зрозуміло, що у процесі адаптації до ВНЗ основну роль відіграють особистісні характеристики студента, але безсумнівно важливі й характеристики навчального закладу.

Далі розглянемо якості особистості, які безперечно впливають на розвіток позиції жертви або агресора кібербулінгу:

1. Цифрова ефективність (популярність у соціальних мережах), тобто оцінка власних можливостей організовувати та виконувати дії, що необхідні для досягнення визначених типів виконання. Підтверджено, що чим сильніше сприймається самоефективність, тим більша ймовірність того, що людина візьметься за виконання того чи іншого завдання. У той час як люди зазвичай ухиляються від завдань, де їхня самоефективність низька, вони будуть займатися завданнями, де вони більш оптимістично налаштовані щодо своїх можливостей. Наприклад, поведінка стосовно здоров'я, (відмова від куріння, фізичні вправи, гігієна зубів та ін.) залежить від уявлення людини про самоефективність. Також 3'ясовано, що високий рівень самоефективності покращує академічну успішність студентів. У традиційних дослідженнях кібербулінгу дослідники також показали, що студенти 3 вищою самоефективністю були більш схильні до залякування.

Інтернет-ефективність прийнята для вимірювання сприйняття або судження індивіда щодо здатності виконувати завдання в доменах Інтернетдодатків. У порівнянні з самоефективністю, це більш специфічна конструкція, яка підкреслює ефективне встановлення, ремонтопридатність та використання загального використання Інтернету. Більшість кібер-хуліганів вважали себе інтернет-експертами, тобто люди з більш високим рівнем самоефективності в Інтернеті вірогідніше братимуть участь у кібер-булінгу.

2. Мотивація. Мотивація керована цілями. У цьому дослідженні ми зосереджуємось на владі, увазі та визнанні як інструментальних рушійних силах поведінки кібер-булінгу. Влада - це бажання контролювати інших або впливати на них. Оскільки роль влади, як правило, підкреслюється у суспільстві, організаціях, люди намагаються за допомогою агресивних дій, таких як кібер-залякування, встановити владу та продемонструвати примусову владу над іншими, а також підвищити самооцінку, що веде до певного рівня саморозвитку.

Прагнення уваги притаманне людській природі і $є$ мотивом більшості наших дій. Студенти часто мають погану поведінку, щоб привернути увагу інших, а не завдати шкоди іншим. Привернення уваги також було підтверджено як мотивація традиційного булінгу.

Прийняття - це прагнення до схвалення суспільства або однолітків. Кіберхулігани можуть вчинити знущання або кібер-залякування, щоб отримати схвалення однолітків; наприклад, щоб справити враження на своїх друзів. 
Встановлено, що особливо студентська молодь, отримують задоволення, підвищенну самооцінку, коли отримують соціальне схвалення від своїх однолітків.

3. Досвід жкертви кібербулінгу. Набуття або корегування поведінки завжди відбувається в результаті навчання та спостереження. Соціальна когнітивна теорія стверджує, що люди можуть спостерігати за поведінкою інших, а потім відтворювати ті самі дії. Гіпотеза циклу насильства також постулює, що люди навчаються насильницькій поведінці, стаючи жертвами агресивної поведінки.

Емпіричні дані значною мірою підтверджують обидві теорії. Так, агресія молодих людей часто виникає з їхнього власного досвіду віктимізації.

Попередні дослідження кібер-булінгу виявили позитивний вплив досвіду кібервіктимізації на поведінку кібер-залякування. Люди, які стали жертвами кібер-булінгу, більш вірогідно схильні здійснювати кібер-залякування в майбутньому під час навчання через 4відтворення поведінки інших хуліганів.

4. Cmamb. Чоловіки більш агресивні, ніж жінки. Ця гендерна відмінність у здійсненні агресивних дій може бути зумовлена біологічною схильністю. Гендерну відмінність агресивної поведінки також можна пояснити традиційними гендерними ролями та культурними нормами. Традиційно для чоловіків цінується сміливість, незалежність та агресивність, тоді як від жінок очікується доброзичливість і терпимість. У кожній культурі чоловіки взяли на себе домінуючу роль для захисту своїх сімей і країн.

У контексті нашого дослідження підкреслимо, що серед опитуваних вчинили кібер-залякування більше половини чоловіків, порівняно з набагато нижчим відсотком для жінок. Тому, констатуємо що гендерний стереотип все ще зберігається у сфері кібер-булінгу.

\section{5. Соціальні норми}

Відповідно до соціально-когнітивної теорії, соціальний вплив як фактор середовища може формувати поведінку особистості. Соціальний вплив $\epsilon$ важливим джерелом «словесного переконання»; воно схоже на концепцію соціальної норми, яка стосується сприйняття індивідом того, що люди, які для нього важливі, думають, що він чи вона повинні чи не повинні виконувати певні дії. Студенстська молодь, що дотримувалася переконань щодо агресивної поведінки, частіше так себе і поводили. Про подібні висновки повідомляють дослідження традиційного булінгу. Аналогічно, в контексті дослідження молоді люди з більшою ймовірністю будуть брати участь у кібер-залякування, якщо однолітки схвалять таку поведінку.

Висновки. Основною метою даного дослідження було дослідити фактори, що визначають поведінку студентів університету, яка призводить до кіберзалякування та кіберагресії. Можемо стверджувати, що як особистісні фактори, так і фактори навколишнього середовища $є$ важливими провісниками поведінки кібер-булінгу. 
Відповідно до соціальної когнітивної теорії та попередніх досліджень традиційного булінгу, було виявлено, що самоефективність в Інтернеті (популярність) має значний позитивний вплив на поведінку кібер-залякування. Студенти університету, які мали досвід роботи в Інтернеті та використанні інтернет-додатків, з більшою ймовірністю могли б чинити різні типи онлайнзалякування (наприклад, надсилали образливі повідомлення, змінювали зображення або публікували відео) без сторонньої технічної допомоги.

Крім того, відповідно до соціальної когнітивної теорії, гіпотези циклу насильства та попередніх досліджень кібер-булінгу, було виявлено, що досвід кібервіктимізації має позитивний вплив на ймовірність кібер-залякування. Студенти університету, можливо, навчилися такій поведінці зі свого досвіду, коли були жертвами кібер-залякування. Вплив насильства також могло зменшити їхнє сприйняття негативних наслідків агресивної поведінки i, таким чином, зменшити їхнє гальмування у виконанні такої поведінки.

Соціальні норми також мають значний вплив на ймовірність кібер-булінгу. Відповідно до положень соціально-когнітивної теорії, здобувачі університетів мали більшу тенденцію до кібер-залякування, коли вони мали переконання щодо такої поведінки (тобто коли вони вірили, що важливі для них люди схвалюють таку поведінку).

Було також виявлено, що мотивація є найсильнішим провісником кібербулінгу. Студенти університету, які бажали влади, уваги та /або схвалення однолітків, значно частіше чинили кібер-залякування. Цей висновок узгоджується з висновком Р. Кемпбелла, який визначив самооцінку як потребу у прийнятті та соціальному схваленні як основні чинники, що сприяють агресивним діям. Цей висновок також узгоджується 3 його дослідженням, яке показує що здобувачі були більш схильні до кібер-домагань, коли вони потребували соціального визнання або схвалення.

Було виявлено також, що як вік, так і стать є важливими провісниками поведінки кібер-булінгу. Студенти університету, які були старшими (показник когнітивної та емоційної зрілості), були менш схильні до кібер-залякування, i цей висновок узгоджується 3 результатами попередніх досліджень i підтверджує наші очікування. Інтернет (який забезпечує анонімність у спілкуванні) надає ідеальну платформу для вчинення такої реляційної / вербальної агресії, як поширення чуток, виключення когось із їхньої соціальної мережі та розсилання повідомлень. Майбутні дослідження можуть додатково досліджувати гендерний вплив на різні типи поведінки кібер-залякування.

\section{Лimepamypa:}

1. Finn J. (2004). A survey of online harassment at a university campus. J. Interpers. Violence 19, 468-481. doi: 10.1177/0886260503262083

2. Lindsay M., Krysik J. (2012). Online harassment among college students: a replication incorporating new Internet trends. Inf. Commun. Soc. 15, 703-719. doi: 10.1080/1369118X.2012.674959 
3. Faucher C., Jackson M., Cassidy W. (2014). Cyberbullying among university students: gendered experiences, impacts, and perspectives. Educ. Res. Int. 2014:698545. doi: 10.1155/2014/698545

4. Baker R. W., Siryk B. (1984). Measuring adjustment to college. J. Couns. Psychol. 31, 179-189. doi: 10.1037/0022-0167.31.2.179

5. Souza, S. B., Veiga, A. M., Ferreira, A. I., and Costa, P. (2018). University students' perceptions of campus climate, cyberbullying and cultural issues: implications for theory and practice. Stud. High Educ. 4, 2072-2087. doi: 10.1080/03075079.2017.1307818

6. Zalaquett C. P., Chatters, S. J. (2014). Cyberbullying in college: frequency, characteristics, and practical implications. Sage Open 4, 1-8. doi: 10.1177/2158244014526721

\section{References:}

1. Finn J. (2004). A survey of online harassment at a university campus. J. Interpers. Violence 19, 468-481. doi: 10.1177/0886260503262083

2. Lindsay M., Krysik J. (2012). Online harassment among college students: a replication incorporating new Internet trends. Inf. Commun. Soc. 15, 703-719. doi: 10.1080/1369118X.2012.674959

3. Faucher C., Jackson M., Cassidy W. (2014). Cyberbullying among university students: gendered experiences, impacts, and perspectives. Educ. Res. Int. 2014:698545. doi: $10.1155 / 2014 / 698545$

4. Baker R. W., Siryk B. (1984). Measuring adjustment to college. J. Couns. Psychol. 31, 179-189. doi: 10.1037/0022-0167.31.2.179

5. Souza, S. B., Veiga, A. M., Ferreira, A. I., and Costa, P. (2018). University students' perceptions of campus climate, cyberbullying and cultural issues: implications for theory and practice. Stud. High Educ. 4, 2072-2087. doi: 10.1080/03075079.2017.1307818

6. Zalaquett C. P., Chatters, S. J. (2014). Cyberbullying in college: frequency, characteristics, and practical implications. Sage Open 4, 1-8. doi: 10.1177/2158244014526721 